\title{
Techno-Economic Analysis of Photovoltaic Utilization for Lighting and Cooling System of Ferry Ro/Ro Ship 500 GT
}

\author{
Danny Faturachman ${ }^{1, *}$, Erkata Yandri ${ }^{2,3}$, Endang Tri Pujiastuti ${ }^{4}$, Olga Anne ${ }^{5}$, \\ Roy Hendroko Setyobudi ${ }^{2,6}$, Yahya Yani $^{7}$, Herry Susanto ${ }^{2,8}$, Washington Purba ${ }^{2,9}$, and \\ Satriyo Krido Wahono ${ }^{10}$ \\ ${ }^{1}$ Department Marine Engineering, Faculty of Ocean Technology, Darma Persada University, \\ J1. Taman Malaka Selatan, Pondok Kelapa, Jakarta 13450, Indonesia \\ ${ }^{2}$ Graduate School of Renewable Energy, Darma Persada University, Jakarta, Indonesia \\ ${ }^{3}$ Center of Renewable Energy Studies, Darma Persada University, Jakarta, Indonesia \\ ${ }^{4}$ Department Management, Faculty of Economic, Darma Persada University, Jakarta, Indonesia \\ ${ }^{5}$ Department of Natural Sciences, Faculty of Marine Technology and Natural Sciences of \\ Klaipeda University, Lithuania \\ ${ }^{6}$ Department of Agriculture Science, Postgraduate Program, University of Muhammadiyah Malang, \\ Jl. Raya Tlogomas No. 246, Malang, 65145, Indonesia \\ ${ }^{7}$ Department of Built Environment and Energy Technology, Faculty of Technology, \\ Linnaeus University, Lückligs plats 1 (Hus M), 35195 Växjö, Sweden \\ ${ }^{8}$ Department of Mechanical Engineering, Darma Persada University, Jakarta, Indonesia \\ ${ }^{9}$ JAP-Energia, Graha Mampang, Lt. 3, Suite 305, Jl. Mampang Prapatan Raya Kav. 100, \\ Jakarta 12760 , Indonesia \\ ${ }^{10}$ Research Division for Natural Product Technology - Indonesian Institute of Sciences, \\ Jl. Jogja - Wonosari, km 31.5, Gunung Kidul, Special Region Yogyakarta 55861, Indonesia
}

\begin{abstract}
The purpose of this study is to perform the techno-economic analysis of photovoltaic system utilization for lighting and cooling of Ferry Ro/Ro 500 GT. The world is facing a dilemma of increasing dependence on fossil energy with decreasing supply. This situation must be anticipated by all sectors by energy efficiency (EE) and utilizing renewable energy (RE). Especially for RE in the transportation sector, ships as consumers of oil energy can also take advantage of solar energy sources, for example for lighting and cooling. For that purpose, five steps must be taken. First, determine the design specifications. Second, determine the specifications of components of the PV system. Third, calculate the power required for lighting equipment. Fourth, calculate the power required for the cooling system. Fifth, make an investment comparison for propulsion systems between diesel engines and photovoltaic systems. The results show that the energy required for lighting and cooling system as well as for propulsion systems can be placed in the deck area of $148.8 \mathrm{~m}^{2}$ for all system components, such as; PV modules, charge controllers, batteries, and inverter. This study can provide an overview of the use of PV system in designing the environmentally new or renovation ships.
\end{abstract}

Keywords: Green transportation, energy saving, solar energy, energy dilemma, ship design

* Corresponding author: fdanny30@yahoo.com 


\section{Introduction}

According to IEA [1], the world is facing a dilemma of increasing dependence on fossil energy such as oil, gas, and coal with decreasing their supply. Especially for Indonesia, this situation must be anticipated by all sectors with implementing energy efficiency (EE) and utilizing renewable energy (RE). The RE included geothermal, biomass, hydro, wind, solar, wave and others, has the potential to be superior in comparison to fossil energy. For achieving EE, energy audits are important $[2,3]$. Both EE and RE are very important to support national energy security [4].

Especially for RE in the transportation sector, ships as consumers of oil energy can also take advantage of solar energy sources, for example for lighting and cooling. In the utilization solar energy in Indonesia as equatorial and tropical areas with the land area of almost $2 \times 10^{6} \mathrm{~km}^{2}$, endowed with irradiating the sun more than $6 \mathrm{~h} \mathrm{~d}^{-1}$ or about $2400 \mathrm{~h}$ in a year. With a geographic location on the equator, Indonesia will always have sunlight for $10 \mathrm{~h}$ until $12 \mathrm{~h}$ a day and approximately daily irradiation of $4.5 \mathrm{kWh} \mathrm{m}^{-2}$ with the monthly variation of about $10 \%$ [5]. Solar energy utilization for Indonesia has various advantages such as: The energy is available with large numbers in Indonesia. Strongly support the national energy policy of austerity. Verified and equitable energy. Allow built-in remote areas because it does not require the transmission of energy or transportation of energy resources.

Solar energy is an environmentally friendly energy source which can be converted to; electrical energy using solar cell or photovoltaic (PV), thermal with solar collector, or both electrical and thermal energy [6,7]. Photovoltaic has been applied in Marine Engineering [8], such as; a passenger ferry [9, 10], cruise ship [11], bulk carrier [12], survey vessel or tanker [13]. Figure 1 shows a patented solution developed by Eco Marine Power that combines sail power (using rigid sails) with solar power. This wind-assisted propulsion (WAP) system also include marine solar power and is designed so that the practical limitations of using rigid sails and solar panels on ships are overcome [14]. As an archipelagic country, Indonesia is highly dependent on ferries for marine transportation and regional development [15]. The generator choice is specialized in idealizing systems in this role for planning because it involves a techno-economy problem. The purpose of this study is to perform the techno-economic analysis of photovoltaic system utilization for lighting and cooling of Ferry Ro/Ro 500 GT to be operated in Indonesian seas.

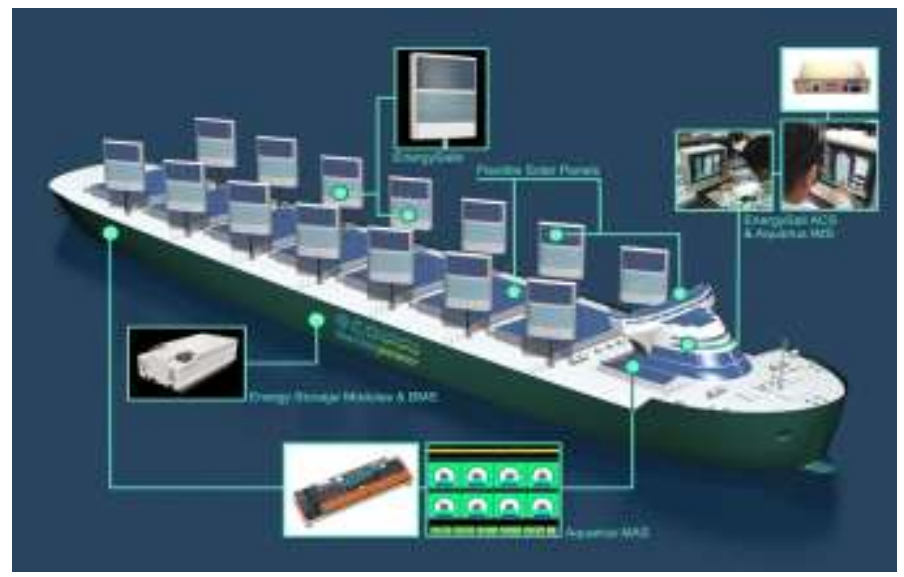

Fig 1. Sail power with solar cell in ship 


\section{Method}

To realize the objectives of this research, there are five steps taken;

First, to determine the design specifications of the ship; Ferry Ro/Ro 500 GT, as shown in Table 1.

Table 1. Specification design of the ship

\begin{tabular}{ll}
\hline Length Over All (LOA) & $45.05 \mathrm{~m}$ \\
Length between Perpendicular (LPP) & $40.15 \mathrm{~m}$ \\
Length of Water Line (LWL) & $42.00 \mathrm{~m}$ \\
Breadth (B) & $12.00 \mathrm{~m}$ \\
Height (H) & $3.20 \mathrm{~m}$ \\
Draft (T) & $2.15 \mathrm{~m}$ \\
Velocity (V & $11 \mathrm{knot}$ \\
Main Engine & $2 \times 800 \mathrm{HP}$ \\
Auxiliary Engine & $2 \times 80 \mathrm{kVA}$ \\
Gen-set emergency & $25 \mathrm{KVa}$ \\
\hline
\end{tabular}

This study focuses on Ferry Ro/Ro (Roll-on/Roll-off) with the horizontal transfer charge [4]. The power for lightings are distributed for; i). the main lighting using fluorescent and neon lamps. ii). emergency lighting lamps mounted at the steering wheel, desk maps, alleys, stairs, engine room, iii). lightings for the engine room, bathroom/toilet, kitchen and rooms open from types that are waterproof (watertight).

Second, determine the specifications of the main components for the PV system. The main components are included; PV module, inverter, charge controller, and battery. The details are shown in Table (2, 3, 4 and 5).

Table 2. Specification of PV module [16]

\begin{tabular}{ll}
\hline PV module type & PV Energy, FVG 240P - MC: \\
Dimension & $(1650 \times 990 \times 35) \mathrm{mm}$ \\
Power peak, $P_{m p p}$ & $240 \mathrm{~W}$ \\
Efficiency, $\eta_{p v}$ & $14.6 \%$ \\
Voltage module, $V_{m p p}$ & $30.50 \mathrm{~V}$ \\
Current module, $I_{m p p}$ & $7.88 \mathrm{~A}$ \\
Open circuit voltage $V_{p v, o c}$ & $37.60 \mathrm{~V}$ \\
Short circuit current $I_{p v, o c}$ & $8.28 \mathrm{~A}$ \\
\hline
\end{tabular}

In designing this PV system, the current resulting from the PV module is the DC, while the current that is used to drive the compressor using the AC current. The DC from the PV module needs to be converted to AC using the inverter current. Table 3 shows the specification of the inverter:

Table 3. Specification of the inverter [17]

\begin{tabular}{ll} 
Inverter type & XANTREX model SW3024E \\
Power & $3300 \mathrm{~W}$ \\
Voltage & $24 \mathrm{~V}$ \\
Efficiency & $94 \%$ \\
\hline
\end{tabular}


Table 4. Specification of the charge controller [18]

Charge controller type

Charging current capacity, $I_{c c}$

Charging voltage, $V_{c c}$
Marine Batteries, Rolls Series 5000

$60 \mathrm{~A}$

$12 \mathrm{~V}$

Table 5. Specification of battery [18]

\begin{tabular}{ll} 
Battery type & Marine Batteries, Rolls Series 5000 \\
Capacity, $P_{b a t}$ & $370 \mathrm{Ah}$ \\
Battery voltage, $V_{b a t}$ & $12 \mathrm{~V}$ \\
\hline
\end{tabular}

The number of panels $N_{p v}$ to meet the needs for a daily hour $h$ of total energy $E_{\text {tot }}$ calculated with:

$$
N_{p v}=\frac{E_{t o t}}{P_{p v} x h}
$$

The number of the charge controller $N_{c c}$ required can be calculated from;

$$
N_{c c}=\frac{N_{p v}}{\left(I_{c c} / I_{p v}\right)}
$$

where, $I_{c c}=60 \mathrm{~A}$, is the maximum current of the charge controller. The total output of charge controller can be calculated as;

$$
I_{c c, t o t}=I_{c c} \times N_{c c}
$$

The power output of the charge controller $P_{c c, t o t}$ with voltage $V_{c c}(12 \mathrm{~V})$ can be calculated as;

$$
P_{c c, t o t}=I_{c c, t o t} \times V_{c c}
$$

The energy saved by a battery $E_{b a t}$ with the capacity $P_{b a t}$ and voltage $V_{b a t}$ of $12 \mathrm{~V}$ can be calculated as;

$$
E_{b a t}=P_{b a t} \times V_{b a t}
$$

The total battery required $N_{b a t}$ to support the total energy load $E_{t o t}$ can be calculated as;

$$
N_{b a t}=\frac{E_{t o t}}{E_{b a t}}
$$

The total energy saved by the batteries $E_{b a t, t o t}$ can be calculated as;

$$
E_{b a t, t o t}=E_{b a t} \times N_{b a t}
$$

The number of inverters $N_{i n v}$ required can be calculated from; 


$$
N_{i n v}=\frac{P_{p v, t o t}}{\left(P_{i n v, i n}\right)}
$$

where, $P_{p v, t o t}$ and $P_{i n v, i n}$ are the total power of the PV module and the power input of the inverter, respectively.

Figure 2 shows the placement of the PV module on the deck wheelhouse. The installation was parallel to optimize the solar energy with proper layout [19]. The PV module of FVG 240P-MC model was considered to address the needs of load for lighting, with sufficient area on the deck of $160 \mathrm{~m}^{2}$.

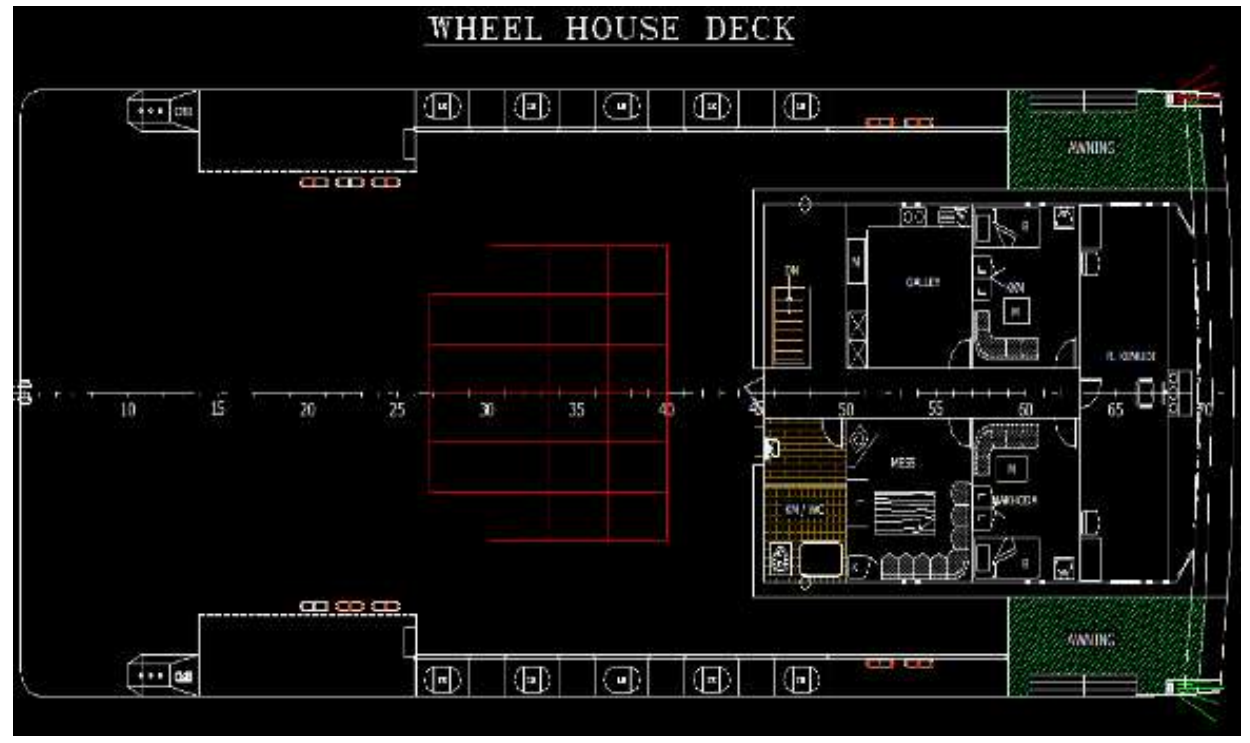

Fig. 2. The placement of solar panel in deck house

Third, calculate the power required for the lighting equipment. The summarized detail of group lighting can be seen in Table 6 .

Table 6. Power required for lighting

\begin{tabular}{lccccc}
\hline \multicolumn{1}{c}{ Deck } & $\begin{array}{c}\text { Load range } \\
\text { (W) }\end{array}$ & $\begin{array}{c}\text { Used hour } \\
\text { (h) }\end{array}$ & Operation & Total (pcs) & Energy (kWh) \\
\hline Bottom & 5 to 20 & 12 & $18: 00$ to $16: 00$ & 8 & 1.74 \\
Vehicle & 5 to 40 & 12 & $18: 00$ to $16: 00$ & 44 & 9.36 \\
Passenger & 5 to 60 & 12 & $18: 00$ to $16: 00$ & 53 & 12.72 \\
Navigation & 5 to 60 & 12 & $18: 00$ to $16: 00$ & 34 & 9.78 \\
\hline & & & Total & 139 & 33.6 \\
\cline { 5 - 6 }
\end{tabular}

Fourth, calculate the power required for the cooling system. As shown in Table 7, the power required for the cooling system is used for Steering Room, Passenger Rooms, Cabin Crew Rooms and the Control Room, installed air conditioning (AC) machine in the form of AC Split in each room. AC Blower must be arranged so that every part of the room to get the same temperature influence. Engine/generator AC should be placed outdoors and protected from direct weather influences and the sea air or given a construction for protection against the weather. The AC generators were placed on the vehicle load space 
must be given a protective fender, or construction to protect the generator from the possibility of a collision with a vehicle. There are 3 factors to consider when determining the need for PK of AC power conditioners, namely AC power $\left(B T U h^{-1}\right)$, electrical power (W), and PK of the AC compressor. Number PK on AC power is a unit on the AC compressor, not $\mathrm{AC}$ cooling power, so to decide on the power need, we must look from the specification of $\mathrm{AC}$.

Table 7. Power required for cooling system

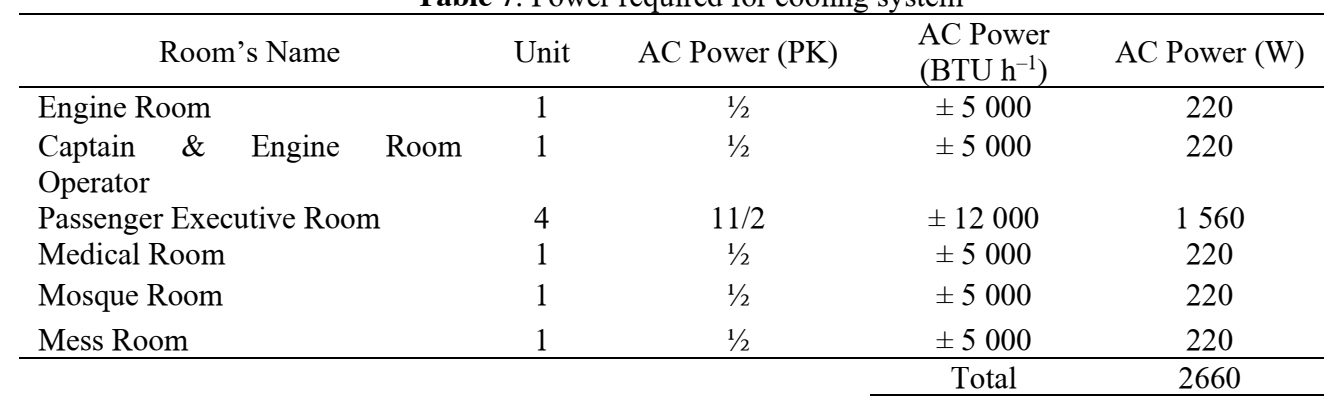

Fifth, make an investment comparison for propulsion systems between diesel engines and photovoltaic systems.

\section{Result and discussion}

\subsection{Power for lighting system}

From the selection of the solar panels, it can be calculated how many pieces of solar panels needed to meet the needs of power for lighting load. For conditions in Indonesia, even though the duration of the sun shines for $8 \mathrm{~h} \mathrm{~d}^{-1}(08.00-16.00)$, but the effectiveness of the photon beam obtained solar panels during the day is $5 \mathrm{~h}, h$. Thus, the number of panels $N_{p v}$ to meet the needs of daily energy $E_{\text {tot }}$ of $33.6 \mathrm{kWh}$ (see Table 6) is 28 unit with additional 7 unit as a backup to anticipate the low irradiation less than $1000 \mathrm{~W} \mathrm{~m}^{-2}$. With extensive consideration of the deck, the platform is still able to accommodate the number of solar panels, in addition to the power generated will be greater or in other words the addition of solar panels to add the amount of power generated. The amount of power generated by the 35 solar panels in $1 \mathrm{~h}: 35$ panels $\times 240 \mathrm{~W}=8.4 \mathrm{~kW}$. The amount of power generated by the solar panels is in $5 \mathrm{~h}$ is $8.4 \mathrm{~kW} \times 5 \mathrm{~h}=42 \mathrm{kWh}$. It has solar panels power largest enough to area on the bridge deck $20 \mathrm{~m} \times 8 \mathrm{~m}=160 \mathrm{~m}^{2}$ and is installed with a slope of $150^{\circ}$ [13]. From the specification of the charge controller, the maximum current can be released is $60.0 \mathrm{~A}$. The summary of the result can be seen in Table 8 .

Table 8. Components and power required for lighting

\begin{tabular}{lclll}
\hline Items & Eq. & Unit & Remarks \\
\hline Number of PV panels, $N_{p v}$ & $(1)$ & $\mathrm{pcs}$ & 28 & With additional 7 pcs $=35 \mathrm{pcs}$ \\
Number of the charge controller, $N_{c c}$ & $(2)$ & $\mathrm{pcs}$ & 5 & \\
Total current of the charge controller, $I_{c c, t o t}$ & $(3)$ & $\mathrm{A}$ & 300 & \\
Total power of the charge controller, $P_{c c, t o t}$ & $(4)$ & $\mathrm{kW}$ & 3.6 & \\
& & & & \\
Energy saved by the batter, $E_{b a t}$ & $(5)$ & $\mathrm{kWh}$ & 4.3 & \\
Number of battery required, $N_{b a t}$ & $(6)$ & $\mathrm{pcs}$ & 10 & \\
The total energy saved by the batteries, & $(7)$ & $\mathrm{kWh}$ & 43 \\
$E_{b a t, \text { tot }}$ & & & & \\
Number of inverters required, $N_{i n v}$ & $(7)$ & $\mathrm{pcs}$ & 11 & \\
\hline
\end{tabular}




\subsection{Power for cooling system}

According to Table 7, The power requires for AC on board during the cruise of $10 \mathrm{~h}$ is $2.66 \mathrm{~kW} \times 10 \mathrm{~h}=26.6 \mathrm{kWh}$. With so many panels to meet the needs of power equal to $26.6 \mathrm{~kW}$ as many as the efficiency of solar panel hence: $240 \times 14.6 \%=204.96 \mathrm{~W}$. The number of solar panel $=(26.6 \mathrm{kWh}) /(204.96 \mathrm{~W} \times 5 \mathrm{~h}) \approx 26$ solar panels. The amount of power generated by the solar panel in $1 \mathrm{~h}$ is $26 \mathrm{PV}$ modules $\times 204.96 \mathrm{~W} \mathrm{PV}^{-1}$ module $=$ $5328.96 \mathrm{kWh}$. The magnitude of the power generated by the PV module all over in $5 \mathrm{~h}$ is $5328.96 \mathrm{kWh} \times 5 \mathrm{~h}=26644.8 \mathrm{kWh}$. From the existing controller charger specifications, the maximum current that can be issued charger controller is of $60 \mathrm{~A}$. The current generated by a solar module with voltage of $30.5 \mathrm{~V}$ is $7.88 \mathrm{~A}$. One charger controller can be used for 7 units of PV modules. The summary of the result can be seen in Table 9.

Table 9. Components and power required for cooling system

\begin{tabular}{llllllll}
\hline Items & Eq. & Unit & \multicolumn{2}{c}{ Remarks } \\
\hline Number of the PV modules, $N_{p v}$ & $(1)$ & pcs & 7 & With additional 7 & pcs & $=$ \\
& & & & 35 pcs & & \\
Number of charge controller, $N_{c c}$ & $(2)$ & pcs & 4 & & & \\
Total current of the charge controller, $I_{c c, t o t}$ & $(3)$ & $\mathrm{A}$ & 240 & Max 60 A/charge controller \\
Total power of the charge controller, $P$ cc,tot & $(4)$ & $\mathrm{kW}$ & 5.76 & & & \\
Energy saved by the batter, $E_{b a t}$ & $(5)$ & $\mathrm{kWh}$ & 4.4 & & \\
Number of battery required, $N_{b a t}$ & $(6)$ & $\mathrm{pcs}$ & 6 & & \\
Total energy saved by the batteries, $E_{b a t, t o t}$ & $(7)$ & $\mathrm{kWh}$ & 24.5 & & \\
Number of the inverters required, $N_{i n v}$ & $(7)$ & $\mathrm{pcs}$ & 9 & & \\
\hline
\end{tabular}

The PV system components will be placed on the deck of the bridge or on the space under the deck of the vehicle with a total area of $12.4 \mathrm{~m} \times 12 \mathrm{~m}=148.8 \mathrm{~m}^{2}$, as shown in Table 10.

Table 10. Dimensions and weight of system components for PV systems

\begin{tabular}{|c|c|c|c|c|c|c|}
\hline \multirow[b]{2}{*}{ Component } & \multirow[b]{2}{*}{ Dimension (cm) } & \multirow{2}{*}{$\begin{array}{c}\text { Weight } \\
\left(\text { kg unit }^{-1}\right)\end{array}$} & \multicolumn{2}{|c|}{ Lighting System } & \multicolumn{2}{|c|}{ Cooling System } \\
\hline & & & Units & $\begin{array}{l}\text { Weight } \\
\text { (kg total) }\end{array}$ & Units & $\begin{array}{l}\text { Weight } \\
\text { (kg total) }\end{array}$ \\
\hline PV module & $165 \times 99 \times 3.5$ & 21.5 & $\begin{array}{c}28 \\
(+7)\end{array}$ & 752.5 & 7 & 150.5 \\
\hline $\begin{array}{l}\text { Charge } \\
\text { controller }\end{array}$ & $37 \times 15 \times 15$ & 0.45 & 5 & 2.25 & 4 & 1.8 \\
\hline Battery & $55.9 \times 17.8 \times 6$ & 123.4 & 10 & 1234 & 6 & 738 \\
\hline Inverter & $53.4 \times 38.1 \times 22.9$ & 16 & 11 & 176 & 9 & 144 \\
\hline & & Total & 61 & 2164.75 & 26 & 1034.3 \\
\hline
\end{tabular}

Lighting and cooling with the PV system provide about $1.49 \%$ savings compared to generators.

\subsection{Economic analysis for driving force system}

The cost comparative analysis for driving force system between the diesel engine and PV system can be explained in Table 11 and the investment cost analysis in Table 12. From the calculation for $10 \mathrm{yr}$ time, the investment cost of the PV system is much lower only IDR 553259000 compare to diesel system IDR 3814025000 or, PV system investment is only $15 \%$ than the diesel system. Besides, it is necessary to consider the accident factor which is experienced by the diesel-engined ships [20]. 
Table 11 Cost comparative analysis for ship propulsion system component

\begin{tabular}{|c|c|}
\hline $\begin{array}{l}\text { With motor diesel: } \\
\text { - } 1 \text { unit auxiliary } 80 \mathrm{kVA} \\
\text { - Tool kit engine } \\
\text { The calculation of fuel consumption using } \\
\text { generator power planned } 80 \mathrm{kVA} \text {, for } 10 \mathrm{~h} \\
\text { cruise: } \\
\mathrm{W}_{\text {fo }}: 80 \times 210 \times 10 \times 10^{-6} \times 0.6=0.1008 \mathrm{t} \\
\text { The volume of fuel: } \\
\mathrm{W}_{\mathrm{fo}} / \gamma_{\mathrm{fo}}=0.10 / 0.85=0.11 \mathrm{~m}^{3}=110 \mathrm{~L} \\
\text { The price of diesel fuel for the total fuel } \\
\text { shipping is } 110 \mathrm{~L} \text { and the price of } 1 \mathrm{~L} \text { of } \\
\text { marine diesel is IDR } 8500 \\
\text { The calculation for motor diesel: } \\
\text { Investment for the purchase of diesel } \\
\text { - Generator } 1 \text { unit: IDR } 43000000 \\
\text { - Tool kit-engine } 1 \mathrm{set} \text { IDR } 2000000 \\
\text { Operations: The fuel for the } 5 \text { trips for } \\
1 \mathrm{~d} \text { needs } 110 \mathrm{~L} \\
\text { - } 1 \mathrm{~d} \text { cruise } 110 \mathrm{~L} \times \text { IDR } 8500=\mathrm{IDR} 935000 \\
\text { - For a year IDR } 935000 \times 365 \mathrm{~d}= \\
\text { IDR } 341275000 \\
\text { - For } 5 \text { yr IDR } 341275000 \times 5= \\
\text { IDR } 1706375000 \\
\text { - For } 10 \text { yr }=\text { IDR } 1706375000\end{array}$ & $\begin{array}{l}\text { - With solar cell: } \\
\text { - Use } 26 \text { PV modules } \\
\text { - } 4 \text { charge controller } \\
\text { - } 6 \text { battery } \\
\text { - } 9 \text { inverter } \\
\text { - For } 10 \text { yr usage performed } 4 \text { times engine } \\
\text { maintenance and costs IDR } 6000000 \times 10 \text { : } \\
\text { IDR } 60000000 \\
\text { - Investment for the purchase of PV modules: } \\
\text { - Using } 26 \text { units PV modules @ } \\
\text { IDR } 3139500=\text { IDR } 81627000 \\
\text { - } 4 \text { pieces charger controller @ } \\
\text { IDR } 6490000=\text { IDR } 25960000 \\
\text { - } 6 \text { batteries @ IDR } 9093500= \\
\text { IDR } 54561000 \\
\text { - } 9 \text { inverter @ IDR } 34950000= \\
\text { IDR } 314550000 \\
\text { - } 1 \text { tool kit set engine: IDR } 2,000,000, \\
\text { - Operational battery backup } 6 \text { pieces @ } \\
\text { IDR } 9093500=\text { IDR } 54561000 \\
\text { - Maintenance costs for } 10 \text { yr @ } \\
\text { IDR } 2000000 \text { yr }{ }^{-1}=\text { IDR } 20000000\end{array}$ \\
\hline
\end{tabular}

Table 12. Total Investment

\begin{tabular}{ccc}
\hline Year & Generator & PV System \\
\hline 1 & IDR 341 275000 & IDR 434 329 500 \\
5 & IDR 1 706 375000 & IDR 10 000 000 \\
10 & IDR 1 706 375000 & IDR 20 000 000 \\
After 10 yr & IDR 60 000 000 & IDR 54 561 000 \\
\hline Total & IDR 3 814 025000 & IDR 553 259000 \\
\hline
\end{tabular}

Based on the above results, three technical points need to be discussed here;

First, the requirement or common rules electricity a ship for the power quality [21], such as; supply electricity to vessels needs and neutral body system of a ship grounded on may not except; zinc anode protection system must be a cathode or the outer part body of ship; system limited or local ground as system starting and starting motor in motor fuel combustion; a measuring monitor insulator instrument to the current that circulated no more than $30 \mathrm{~mA}$ in the worst of conditions; high voltage neutral ground to avoid dangerous areas were defined in requirements.

Second, power supply and distribution. Generator, switchboard and battery must be in a separate location from the fuel tank and oil pump, with a cofferdam or with sufficient distance. The cable that might be opened by the steam and gas needs to be protected with the proper insulation, with the possibility of reducing corrosion. Some requirements for the installation cable onboard based on the position where the cables will be placed, adapted to the structure of the ship so that the installation and buffer plate avoid the possibility of strains/stresses.

Third, when docking, ships can use the power of the land through shore connection to avoid emission by the generator [22]. If the generator is not active then the emergency source of electrical power (power source) is usually in the form of battery. Due to the 
nature of the emergency then only certain equipment and very important in the supply by the emergency source of electric power, for example, lights navigation, gangway lighting appliances, and others. The emergency power source will be stored automatically through the emergency switchboard, if all the generators are not active.

The results of this study can provide an overview of the use of PV system in designing the new or renovation ships, both for lighting and cooling systems as well as for propulsion systems. For environmentally friendly shipping [23], future ship design should consider the use of PV module as a technology for converting solar energy into electrical energy. According to the berthing location, the green ship concept can be integrated into the smart city concept with smart grid technology [24, 25]. For the future research direction, this analysis can be developed into a simulation tool with a variety of ship types with optimal placement on the ship [9].

\section{Conclusion}

The analysis of photovoltaic usage for the 500 GT Ferry-Roro has been carried out with several important points, as follows. To meet the energy needs of the lighting system with the existing component specifications; then it takes 28 PV modules, 5 charge controllers, 10 batteries and 11 inverters. As for the cooling system, it is needed 7 PV modules, 4 charge controllers, 6 batteries and 9 inverters. All system components can be placed in the provided deck area of $148.8 \mathrm{~m}^{2}$. Lighting and cooling with the PV system provide about $1.49 \%$ savings compared to generators. PV system investment is only $15 \%$ than the diesel system. For the propulsion, PV system investment is only $15 \%$ than the diesel system.

\section{References}

1. International Energy Agency (IEA). World Energy Outlook 2019. [Online] from https://www.iea.org/reports/world-energy-outlook-2019 (2019). [Accessed on 30 September 2020].

2. E. Yandri, R. Ariati, A.S. Uyun, R.H. Setyobudi, O. Anne, H. Susanto, et al., IOP Conf. Ser. Earth Environ. Sci., 2020:490(2020). https://doi.org/10.1088/1755$1315 / 490 / 1 / 012005$

3. E. Yandri, R. Ariati, A.S. Uyun, R.H. Setyobudi, H. Susanto, K. Abdullah et al., E3S Web of Conf. 190:00008(2020). https://doi.org/10.1051/e3sconf/202019000008

4. E. Yandri, R. Ariati, R.F. Ibrahim, Jurnal Ketahanan Nasional, 24,2:239-260(2018). https://doi.org/10.22146/jkn.30999

5. World Bank Group. Solar Resource and Photovoltaic Potential of Indonesia. [Online] from http://documents1.worldbank.org/curated/en/729411496240730378/pdf/115347ESM-P145273-PUBLIC-IndonesiaSolarResourcePotentialWBESMAPMay.pdf (2017). [Accessed on 01 October 2020].

6. E. Yandri, Sol. Energy Mater. Sol. Cells, 201:110066(2019). https://doi.org/10.1016/j.solmat.2019.110066

7. E. Yandri, Renew. 111:344-352(2017). https://doi.org/10.1016/j.renene.2017.03.094

8. I. Kobougias, E. Tatakis, J. Prousalidis, Adv. Power Electron., 2013:1-8(2013). https://doi.org/10.1155/2013/831560

9. P. Cheng, N. Liang, R. Li, H. Lan, Q. Cheng, Energies 13,1:1(2019). https://doi.org/10.3390/en13010001 
10. J. Ling-Chin, A.P. Roskilly, Appl. Energy., 181:416-434(2016). https://doi.org/10.1016/j.apenergy.2016.08.065

11. Y. Yan, H. Zhang, Y. Long, Y. Wang, Y. Liang, X. Song, et al., J. Clean Prod., 233:264-279(2019). https://doi.org/10.1016/j.jclepro.2019.06.047

12. W. Saidyleigh. Investigation of auxiliary power potentials of solar photovoltaic applications on dry bulk carrier ships. [Dissertation]. Maritime Energy Management, World Maritime University, Sweden (2017). p. 104. https://commons.wmu.se/cgi/viewcontent.cgi?article $=1589 \&$ context=all dissertations

13. H. Lan, J. Dai, S. Wen, Y.Y. Hong, D.C. Yu, Y. Bai, Energies 8:11515-30. https://doi.org/10.3390/en81011515

14. L. Talluri, D.K. Nalianda, K.G. Kyprianidis, T. Nikolaidis, P. Pilidis, Ocean Eng., 121:301-311(2016). https://doi.org/10.1016/j.oceaneng.2016.05.047

15. D. Faturachman, MATEC Web Conf., 177:1-8(2018). https://doi.org/10.1051/matecconf/201817701005

16. FVG Energy. The company fvg energy - production of photovoltaic modules. [Online] from

http://www.verexzilina.sk/www/pages template/template doc.php?lang=sk\&idp=500 $\&$ fid $=100 \&$ tid $=1$ (n.d.). [Accessed on 02 October 2020].

17. Xantrex. FREEDOM SW 3000 Sine Wave Inverter/Charger 2010. [Online] from http://www.xantrex.com/documents/Inverter-Chargers/Freedom-SW-

3000/DS20090915FreedomSWInverterCharger3000Watts.pdf (2010). [Accessed on 03 October 2020].

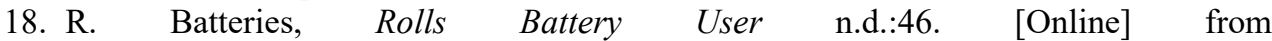
https://rollsbattery.com/public/docs/user_manual/Rolls_Battery_Manual.pdf $\quad$ (n.d.). [Accessed on 04 October 2020].

19. Ç. Karatuğ, Y. Durmuşoğlu, Sol. Energy, 207:1259-12068(2020). https://doi.org/10.1016/j.solener.2020.07.037

20. D. Faturachman, S. Mustafa, F. Octaviany, T.D. Novita, Int. J. Serv. Sci. Manag. Eng.,

1:6-16(2014). http://www.openscienceonline.com/journal/archive2?journalId=729\&paperId=316

21. Y. Qiu, C. Yuan, Y. Sun, X. Tang. Electr. Power Components Syst., 2018;46:137586. https://doi.org/10.1080/15325008.2018.1485185

22. D. Colarossi, P. Principi, Appl. Therm. Eng., 181:115988(2020). https://doi.org/10.1016/j.applthermaleng.2020.115988

23. S. Fang, Y. Wang, B. Gou, Y. Xu, IEEE Trans. Veh. Technol., 69:207-219(2020). https://doi.org/10.1109/TVT.2019.2950538

24. Z. Jin, L. Meng, J.M. Guerrero, R. Han, IEEE Trans. Ind. Informatics, 14:703714(2018). https://doi.org/10.1109/TII.2017.2772343

25. B. Novianto, K. Abdullah, A.S. Uyun, E. Yandri, S.M. Nur, H. Susanto, et al., E3S Web Conf., 188:00005(2020). https://doi.org/10.1051/e3sconf/202018800005 